\title{
Transient Receptor Potential Cation Channel Subfamily M Member 5
}

National Cancer Institute

\section{Source}

National Cancer Institute. Transient Receptor Potential Cation Channel Subfamily M

Member 5. NCl Thesaurus. Code C30131.

Transient receptor potential cation channel subfamily M member 5 (1165 aa, 131 kDa)

is encoded by the human TRPM5 gene. This protein is involved in voltage-dependent calcium transport, which modulates transient neuronal membrane depolarization. 